

\title{
Family Functioning, Resilience, and Cognitive Distortion among Secondary School Students
}

Siti Hajar Mohamad Yusoff, Mohd Sani Ismail, Noor Eliza Abdul Rahman, Mohd Rahim Ariffin, Yahya Don, Muhammad Dzahir Kasa

To Link this Article: http://dx.doi.org/10.6007/IJARBSS/v9-i11/6591 DOI: 10.6007/IJARBSS/v9-i11/6591

Received: 11 October 2019, Revised: 1 November 2019, Accepted: 15 November 2019

Published Online: 26 November 2019

In-Text Citation: (Yusoff et al, 2019)

To Cite this Article: Yusoff, S. H. M., Ismail, M. S., Rahman, N. E. A., Ariffin, M. R., Don, Y., Kasa, M. D. (2019). Family Functioning, Resilience, and Cognitive Distortion among Secondary School Students. International Journal of Academic Research in Business and Social Sciences, 9(11), 695-709.

Copyright: @ 2019 The Author(s)

Published by Human Resource Management Academic Research Society (www.hrmars.com)

This article is published under the Creative Commons Attribution (CC BY 4.0) license. Anyone may reproduce, distribute, translate and create derivative works of this article (for both commercial and non-commercial purposes), subject to full attribution to the original publication and authors. The full terms of this license may be seen

at: http://creativecommons.org/licences/by/4.0/legalcode

Vol. 9, No. 11, 2019, Pg. 695 - 709

http://hrmars.com/index.php/pages/detail/IJARBSS

JOURNAL HOMEPAGE

Full Terms \& Conditions of access and use can be found at http://hrmars.com/index.php/pages/detail/publication-ethics 


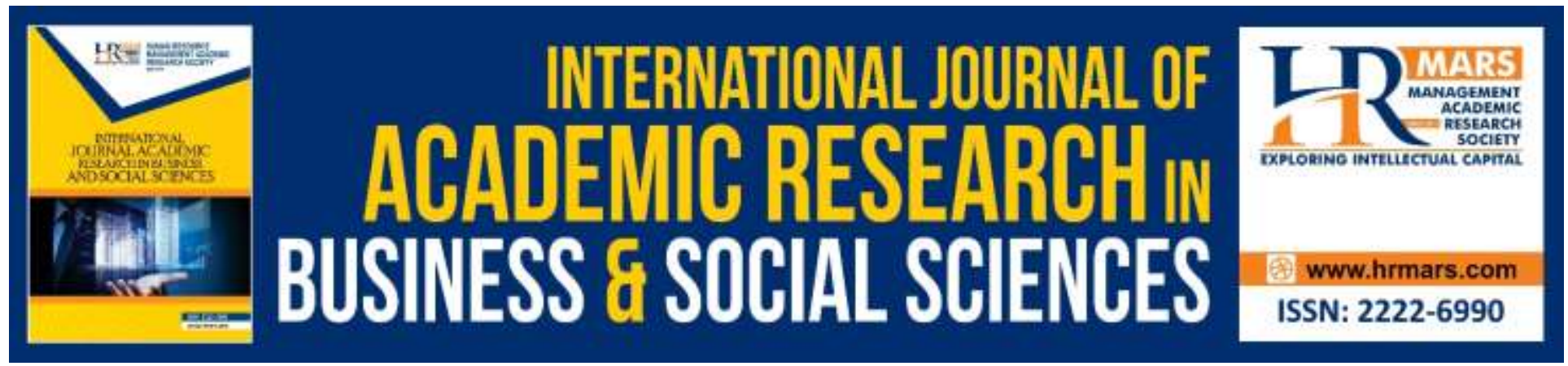

\title{
Family Functioning, Resilience, and Cognitive Distortion among Secondary School Students
}

\author{
Siti Hajar Mohamad Yusoff, Mohd Sani Ismail, Noor Eliza Abdul \\ Rahman, Mohd Rahim Ariffin \\ Faculty of Islamic Contemporary Studies, University of Sultan Zainal Abidin, Malaysia.
}

\author{
Yahya Don, Muhammad Dzahir Kasa
}

School of Education and Modern Languages (SEML), Northern University of Malaysia, Malaysia

\begin{abstract}
In line with the National Education Philosophy (NEP), the Malaysian Education Blueprint (20132025) was launched in order to produce students who are capable of thinking constructively and able to face the obstacles, while developing leadership skills and potential in students. However, family functioning also plays a role in developing students' resilience and positive thinking. Therefore, this study is to identify the relationship between family functioning, resilience, and cognitive distortion among students. The quantitative approach was used in this study, while the cross-sectional surveys applied in the data collection process. The instruments used were Family Adaptability and Cohesion Evaluation Scales III, Resilient Scale, and Cognitive Distortion Scale. A total of 376 respondents from daily secondary school students in the Northern Zone Malaysia were participated in this study. Systematic random sampling and disproportionate stratified random sampling had been used. Quantitative data were analysed by Pearson Correlation using the Statistical Package for Social Science for Windows (SPSS). The findings showed a significant relation between family functioning, resilience, and cognitive distortion. In conclusion, this study has builds a significant theoretical framework about family functioning, resilience, and cognitive distortion among students, as well as being able to contribute to various parties such as school management, counsellors, parents, and researchers in order to produce future leaders who capable in various aspects.

Keywords: Family Functioning, Resilience, Cognitive Distortion, Psychology, Secondary School, Students.
\end{abstract}




\section{Introduction}

Ministry of Education Malaysia is really serious to produce a knowledgeable, well educated, high moral value, and has strong resilience students (PPPM, 2013-2025). This is in line with the National Education Philosophy (NEP) which also emphasizes the element of resilience and cognitive balance in the process of developing individuals who are able to achieve their selfwelfare (Yaakob et al., 2017; Romli, Othman, Abdullah, \& Hamat, 2018). However, in recent years, there are various cases related to social and behavioural issues such as free sex, drug addiction, and bullying. Which involve school students (Azizi et al., 2008; Nasrudin, Suhaimi, \& Lokman, 2013). In fact, many parties have realized the seriousness of this matter and began to think of steps to identify and overcome the factors that contributed to this problem for long-term solutions. This is because, when a student gets less attention since childhood and has less resilience, they will be easily affected and tend to experience cognitive distortion and negative behaviour (Wisena, Maslihah, \& Nurendah, 2016; Jaradat, ALkhazaleh, 2018).

Schafer (2011) and Yaakob et al. (2017) also acknowledges that student education is not merely focused on educational institutions that involve the introduction of certain facts, figures, skills, and experiences, but it is the development and incidence formed from their knowledge and experience through the process of communication within a family which able to function properly or vice versa. In this regard, it is important to note that student resilience in facing current challenges is closely related to the role of parents in developing a well-functioning family (Brian, 2015, Samsiah, Shah, \& Noraini, 2015; Hajar \& Yahya, 2016; Hajar, 2017). This is because, there are students who are facing family problems and are unable to achieve good physiology (Zainah et al., 2013). This is where families need to function well so their children who are also students will be more resilient and not involved with social problems and negative behaviours when they are able to think and manage their cognitive healthily (Khalim, 2008; Poletti, Colombo, \& Benedetti, 2014; Yaakob et al., 2017; Manoli, 2019).

\section{Problem Statement}

Teenagers in today's era of globalization are often vulnerable to social challenges and disease that cause them to become languid and unproductive. The mass media always exhibit warm social symptoms involving teenagers such as loitering, skipping, stealing, drug abuse, free sex, and murder (Azizi et al., 2008; Zainah et al., 2013). For example, teenagers aged from 16 to 19 were found to be the highest group who had suicidal ideas until researchers and also psychiatrists and cognitive therapists confirm that WHO's statistics and the growth in suicidal have shown that it is a serious public health problem and one of the major factors for this problem is a mental health problem (Farhana 2010; Harris \& Barraclough, 1997; Maniam, 2010).

Seriously, it is understandable that students typically behave in such a way when they are under pressure, and what they need is a good interaction within the family (Samsiah, Shah, \& Noraini, 2015). Usually, problematic students come from family backgrounds which are not functioning 
properly and their negative behaviour is introduced by their own family (Houston \& Barton, 2005). Good interaction among family members is able to provide emotional support to students and then will prevent them from doing misconduct (Barnett, 2004; Samsiah, Shah, \& Noraini, 2015).

However, there also issue where family is not properly functioning. In Malaysia, suicide cases are not very noticeable among students. Because of that, when it happens, parents, family members, and schools are not expecting that it can happen. Problematic students who tend to commit suicide are those who have self-conflicts that cause them to feel isolated and have no friends, and their behaviour is getting worse when they feel that their family does not care about them (Zuria, Noriah \& Amla, 2003). Thus, families are seen as a social group which is a major factor in the growth of students, and good family functioning is the determinant of the student growth (Amoateng \& Richter, 2007; Brian, 2015).

In addition, the low resilience of the students has dragged them into a stressful situation, which resulted in them being unable to think positively and then get cognitive distortion until they decided to involve in various unhealthy activities (Fauziah, Bahaman, Mansor, \& Mohamad Shatar, 2012). In fact, studies show that most teenagers aged between 18 and 25 years tend to focus their thoughts on irrational thinking (Nyarko \& Amissah, 2014) where this thought can create emotional stress such as depression that can lead to negative attempts such as suicide (Simon, 1992; Briere, 2000; William \& Garland, 2002).

Although the school leavers continue to study at university level and excel in academics, they still have not escaped from various other problems such as personal, family, identity crisis, and mental health (Shafeq \& Hairiza, 2009). These are often experienced by the students when their cognitive system is related with the negative elements around them, where this situation needs to be faced by them to pursue their life which of course involves certain social groups (Leahy, 1996). What to be worried is that if the problem of family functioning, resilience, and cognitive distortion is not addressed, the students may not be able to withstand thus affecting their behaviour become negative (Jamie, 2011; Poletti et al., 2014; Hajar, Shakirah, \& Fatimah, 2018). Thus, referring to the issues discussed, this study will examine the relationship between family functioning, resilience, and cognitive distortion among form six students in Malaysia.

\section{Research Objective}

This study is generally to examine the relationship between family functioning, resilience, and cognitive distortion among students. Specific objectives for this study are:

i. Examine the level of family functioning, resilience, and cognitive distortion among students.

ii. Identify whether there is a relationship between family functioning, resilience, and cognitive distortion among students. 


\section{Research Models}

The main theoretical framework in the context of this study was based on the formation of Three dimensional (3-D) Circumplex Model (Olson, Russell, \& Sprenkle, 1979), Resilience Model (Russell \& Russell, 2003), and Self Trauma Model (Briere, 1996). These three models have been used to study about family functioning, resilience, and cognitive distortion among students. This is because, these three models are considered parallel and appropriate to the dimensions and variables which emphasized in this study. In fact, three instruments were used in this study have also been developed by the founders of these models. The Family Adaptability and Cohesion Evaluation Scales III (FACES III) instrument developed by Olson, Portner, and Lavee (2003) resulted from the development of the Three Dimensional Circumplex Model (Olson, 1991) which was designed to adapt measurements to see the linear functioning of the family, as can be observed in this study. For example, the higher level of cohesion or adaptability, the better the family functioning.

Next, the Resilient Scale Instrument (RS) introduced by Russell and Russell (2006), is developed from Self Resilience Model (Russell \& Russell, 2003) which emphasized the eight dimensions of resilience as mentioned in this study which are self-assurance, personal vision, flexible, organized, problem solver, interpersonal competence, socially connected, and proactive.

Finally, the Cognitive Distortion Scale (CDS) instrument established by Briere (2000) is developed from the Self-Trauma Model (Briere, 1996) which emphasizes the individual's ability to think in a stressful situation or when forced to face traumatic situation, whether it is pain or fear that can interfere with personal growth such as the individual cognitive relationship and development system, in which this model describes the five dimensions of cognitive distortion which are selfcriticism, self-blame, helplessness, hopelessness, and preoccupation with danger as emphasized in this research.

Research results of Bahremand et al. (2015), Besharat (2007), Garbowsk (2010), Wisena et al. (2016), and Zauszniewski, Bekhet, and Suresky (2009, 2010) relating to family functioning, resilience, and cognitive distortion show the relationship that exists between the three variables. The results of the study Zauszniewski et al. (2009) found that there was a relationship between weak family functioning and low resilience, while low resilience was found to be related with the improvement of cognitive distortion. Wisena et al. (2016) claimed that cognitive distortion in the sense of helplessness existed in the student can be addressed through the formation of family functioning, as well as by developing resilience among students. Her study has indirectly shown the relationship between the three variables were mentioned in this study. Garbowsk (2010) explained that individuals who seek to help themselves and others, and develop themselves regularly are able to cope with the problems of cognitive distortion.

\section{Research Methodology}

This study used the quantitative approach based on cross-sectional survey. Descriptive and inference analysis were used where descriptive analysis is used to see the frequency and 
percentage of respondents, while the correlation technique is used to identify the relationship between the variables. The target population for this study was all the National Secondary Schools in the Northern Zone of Peninsular Malaysia which are Perak, Penang, Kedah and Perlis. A total of 425 schools have been identified, of which 185 schools in Perak, 83 schools in Penang, 138 schools in Kedah, and 19 schools in Perlis, involving 19868 Form Six students who are taking STPM. Furthermore, by looking at the population values, the sample of the students involved as the respondents of the study was determined based on Krejchie and Morgan table (1970) with the amount of 376 samples from 19868 populations.

\section{Sampling}

Based on systematic random sampling from 425 Daily National Secondary School in Perak, Penang, Kedah and Perlis where a total of 21 schools were selected, nine schools in Perak, four schools in Penang, seven schools in Kedah, and a school in Perlis. Furthermore, the selection of student samples was determined using disproportionate stratified sampling method, in which students are selected to be samples determined by gender of students. A total of 30 students comprising 15 boys and 15 girls were selected using the simple random method for each school involved which in Perak, a total of 135 boys and 135 girls were selected, while in Penang, Kedah and Perlis respectively with ratio of 60:60, 105: 105, and 15:15 male and female students were selected. Thus, the 630 students selected as samples were asked to answer a set of questionnaires with clear explanations to ensure that all questionnaires distributed were fully answered and qualified.

\section{Instrument}

A set of questionnaires was used to obtain important information of the study. Questionnaires used in this study consist of four parts. Part A is related to respondents' demographics, Part B is the instrument of Family Adaptability and Cohesion Evaluation Scales III (Olson, Portner, \& Lavee, 2003) which involves 2 dimensions and consists of 20 items. Part C is the Resilient Scale (Russell \& Russell, 2006) which involves 8 dimensions and consists of 32 items. While Part $D$ is a Cognitive Distortion Scale (Briere, 2000) which involves 5 dimensions and consists of 40 items. Overall, all the instruments used have a high degree of reliability and have been used internally and internationally.

\section{Result and Discussion}

Respondents in this study consisted of form six students who are currently taking the Malaysian High Certificate of Education (STPM) at the Daily National Secondary School (STPM) around the Northern Zone in Perak, Penang, Kedah, and Perlis. Based on the Krejchie and Morgan tables (1970), out of the 19,868 student population, 376 respondents were selected to be involved in this study. Table 1 shows descriptive findings for selected respondents' demographics by gender, age, and race categories. 
Thus, based on Table 1, it is known that this study involved 222 (59\%) female students and 154 (41\%) male students. The majority of the respondents are 19 years old students, comprising of 198 peoples (52.7\%) compared to 18 years old students which only 178 peoples (47.3\%). From the aspect of races, the majority of respondents were Malays, 245 (65.2\%), followed by 83 Chineses (22.1\%), 45 Indians (12.0\%), and 3 from others $(0.8 \%)$.

Table 1

\begin{tabular}{llll}
\multicolumn{5}{c}{ Respondents' Demographic } \\
\hline Demographic & & Frequency & Percent \\
\cline { 2 - 3 } & Male & 154 & 41.0 \\
& Female & 222 & 59.0 \\
\multirow{3}{*}{ Age } & Total & 376 & 100.0 \\
& 18 years & 178 & 47.3 \\
\multirow{3}{*}{ Race } & 19 years & 198 & 52.7 \\
& Total & 376 & 100.0 \\
& Malay & 245 & 65.2 \\
& Chinese & 83 & 22.1 \\
& Indian & 45 & 12.0 \\
& Others & 3 & 0.8 \\
& Total & 376 & 100.0 \\
\hline
\end{tabular}

The descriptive analysis results of the students' family functioning are shown in Table 2. It can be noted that the level of family functioning of the respondents was assessed through the two dimensions studied which are cohesion and adaptability.

Table 2

The Level of Family Functioning

\begin{tabular}{lll}
\hline Family Functioning & Mean & SD \\
\hline Family Functioning & 3.39 & 0.45 \\
Resilience & 3.64 & 0.48 \\
Cognitive Distortion & 1.95 & 0.63 \\
\hline
\end{tabular}

Based on the findings in Table 2, it can be concluded that the overall score of the mean score obtained for the respondents of the experienced family respondents was found to be moderate with the value $(M=3.39, S D=.45)$. Students' resilience is also at moderate level with the score 
$(\mathrm{M}=3.64, \mathrm{SD}=.48)$, and in general, students experienced cognitive distortion at a low level based on the mean $(M=1.95 ; S D=.63)$.

Referring to the correlation analysis in Table 3, it is generally found that there is a significant and weak positive relationship between family functioning and students' resilience $(r=.285, p<.01)$. In fact, all dimensions of family functioning are also seen as significant and weak positive relationships with all dimensions of resilience, where it can be noted that the dimensions of cohesion have positive relationships with self-assurance $(r=.206, p<.01)$, personal vision $=.257$, $p<.01)$, flexible $(r=.230, p<.01)$, organized $(r=.267, p<.01)$, problem solver $(r=.249, p<.01)$, interpersonal competence $(r=.213, p<.01)$, socially connected $(r=.178, p<.01)$, and proactive $(r=.242, p<.01)$. These findings directly show that the higher cohesion aspect in family functioning, the higher resilience among the respondents.

Besides that, the adaptability dimension also found to have positive relationship with the selfassurance dimension $(r=.115, p<.01)$, personal vision $(r=.161, p<.01)$, flexible $(r=.136, p<$. $(R$ $=.284, p<.01)$, problem solver $(r=.123, p<.05)$, interpersonal competence $(r=.177, p<.01)$, socially connected $(r=.119, p<.05)$, proactive $(r=.130, p<.05)$, and the overall resilience variable $(r=.194, p<.01)$. The results of this analysis also explain that the higher adaptability aspect in respondents' family functioning, the higher resilience among the respondents.

Table 3

Correlation between Family Functioning and Resilience

\begin{tabular}{llll}
\hline Resilience & \multicolumn{3}{c}{ Family Functioning } \\
& Cohesion & Adaptability & Family \\
& & & $.182^{* *}$ \\
Self-Assurance & $.206^{* *}$ & $.115^{*}$ & $.237^{* *}$ \\
Personal Vision & $.257^{* *}$ & $.161^{* *}$ & $.207^{* *}$ \\
Flexible & $.230^{* *}$ & $.136^{* *}$ & $.315^{* *}$ \\
Organized & $.267^{* *}$ & $.284^{* *}$ & $.211^{* *}$ \\
Problem Solver & $.249^{* *}$ & $.123^{*}$ & $.222^{* *}$ \\
Interpersonal Competence & $.213^{* *}$ & $.177^{* *}$ & $.169^{* *}$ \\
Socially Connected & $.178^{* *}$ & $.119^{*}$ & $.211^{* *}$ \\
Proactive & $.242^{* *}$ & $.130^{*}$ & $.272^{* *}$ \\
Resilience & $.285^{* *}$ & $.194^{* *}$ & \\
\hline$<0.01 ; * \mathrm{p}<0.05$ & & &
\end{tabular}

Overall, the correlation findings between family functioning variables and self-resilience dimensions showed a weak and significant positive relationship between family functioning variables with self-assurance dimension $(r=.182, p<.01)$, personal vision $(r=(R=.207, p<.01)$, 
$\operatorname{organized}(r=.315, p<.01)$, problem solver $(r=.211, p<.01)$, interpersonal competence $(r=.222$, $p<.01)$, socially connected $(r=.169, p<.01)$, as well as proactive $(r=.211, p<.01)$, and also with the resilience variables as a whole $(r=.272, p<.01)$. This analysis explains that the higher respondents' family functioning, the higher level of resilience among the students.

Table 4

Correlation between Family Functioning and Cognitive Distortion

\begin{tabular}{lllllll}
\hline $\begin{array}{l}\text { Family } \\
\text { Functioning }\end{array}$ & \multicolumn{5}{c}{ Cognitive Distortion } \\
& $\mathrm{SC}$ & $\mathrm{SB}$ & $\mathrm{HE}$ & $\mathrm{HO}$ & $\mathrm{PWD}$ & $\mathrm{CD}$ \\
\hline Cohesion & $-.218^{* *}$ & $-.228^{* *}$ & $-.189^{* *}$ & $-.186^{* *}$ & $-.151^{* *}$ & $-.219^{* *}$ \\
Adaptability & $-.126^{* *}$ & -.082 & .018 & .067 & -.001 & -.029 \\
Family & $-.195^{* *}$ & $-.175^{* *}$ & -.095 & -.064 & -.085 & $-.139 * *$ \\
$\quad$ Functioning & & & & & & \\
$* * \mathrm{p}<0.01 ; * \mathrm{p}<0.05$ & & & & & &
\end{tabular}

Generally, the results in Table 4 shows that there is a weak and significant negative relationship between family functioning and cognitive distortion among respondents $(r=-139, p<.01)$. Further analysis found that only cohesion dimension in family functioning had a weak and significant negative relationship with cognitive distortion variables $(r=-.219, p<.01)$, while dimension of adaptability is the opposite $(r=-029, p>$. 05). The analysis also shows a weak and significant negative relationship between family functioning variable and self-criticism dimension $(r=-195, p<.01)$ and self-blame dimension $(r=-175, p<.01)$, while with helplessness $(r=-095$, $p>.05)$, hopelessness $(r=-.064, p>.05)$, and preoccupation with danger dimensions $(r=-.085, p>$ .05) are the opposite. Hence, as a whole, the analysis findings in Table 4 explain that the higher family functioning, the lower level of cognitive distortion experienced by the students.

To further elaborate the findings, the analysis also shows that the dimension of cohesion has a significant and negative significance with all the dimensions of cognitive distortion which involve the dimension of self-criticism $(r=-.218, p<.01)$, self-blame $(r=-288, p<.01)$, helplessness $(r=-$ $.189, p<.01)$, hopelessness $(r=-186, p<.01)$, and preoccupation with danger $(r=-.151, p<.01)$. This result explains that the higher cohesion in respondent's family functioning, the lower level of cognitive distortion experienced by students.

Referring to the findings of the correlation for the dimension of adaptability, there was a weak and significant negative relationship with the self-criticism dimension $(r=-126, p<.01)$, while there was no significant relationship between dimension of adaptability and the other four dimensions of self-blame $(r=-082, p>.05)$, helplessness $(r=.018, p>.05)$, hopelessness $(r=.067$, $p>.05)$, and preoccupation with danger $(r=.001, p>.05)$. This shows that the growing of 
adaptability aspect in respondent's family functioning, the lower the level of self-criticism dimensions of cognitive distortion experienced. Overall, the findings show that the better level of family functioning, the lower level of student cognitive distortion.

Based on the findings of correlation in Table 5, it is generally found that there was a significant and weak negative relationship between self-resilience and cognitive distortion $(r=-341, p<.01)$. In fact, all dimensions of cognitive distortion have a significant and weak negative relationship with all dimensions of self-resilience, except dimension of self-blame that have no relation to social relationship dimension $(r=-059, p>.05)$. In addition, self-criticism dimension was found to have a weak and significant negative relationship with all dimensions of resilience which are selfassurance $(r=-373, p<.01)$, personal vision $(r=-317, p<.01)$, flexible $(r=-315, p<.01)$, organized $(r=-312, p<.01)$, problem solver $(r=-312, p<.01)$, interpersonal competence $(r(R=-.150, p$ $<.01)$, proactive $(r=-249, p<.01)$, and the overall resilience variable $(r=-.343, p<.01)$. These findings show that the higher level of student's resilience, the lower level of self-criticism experienced by students.

Table 5

Correlation between Resilience and Cognitive Distortion

\begin{tabular}{|c|c|c|c|c|c|c|}
\hline \multirow[t]{2}{*}{ Resilience } & \multicolumn{6}{|c|}{ Cognitive Distortion } \\
\hline & SC & SB & $\mathrm{HE}$ & $\mathrm{HO}$ & PWD & CD \\
\hline Self-Assurance & $-.373 * *$ & $-288 * *$ & $-.369 * *$ & $-.354 * *$ & $-.327^{* *}$ & $-.384 * *$ \\
\hline Personal Vision & $-.317^{* *}$ & $-276 * *$ & $-.337 * *$ & $-.304^{* *}$ & $-.214 * *$ & $-.326 * *$ \\
\hline Flexible & $-.315^{* *}$ & $-232 * *$ & $-.340 * *$ & $-.302 * *$ & $-.257^{* *}$ & $-.325^{* *}$ \\
\hline Organized & $-.312 * *$ & $-226 * *$ & $-.239 * *$ & $-.152 * *$ & $-.254 * *$ & $-.267 * *$ \\
\hline Problem Solver & $-.312 * *$ & $.270 * *$ & $-.368 * *$ & $-.341 * *$ & $-.226 * *$ & $-.341^{* *}$ \\
\hline Interpersonal Competence & $-.198 * *$ & $.147^{* *}$ & $-.208 * *$ & $-.158 * *$ & $-.150 * *$ & $-.194 * *$ \\
\hline Socially Connected & $-.150 * *$ & -.059 & $-.126^{*}$ & $-.132 *$ & $-.233 * *$ & $-.157 * *$ \\
\hline Proactive & $-.249 * *$ & $.171^{* *}$ & $-.239 * *$ & $-.215^{* *}$ & $-.129 *$ & $-.225^{* *}$ \\
\hline Resilience & $-.343^{* *}$ & $.256 * *$ & $-.341 * *$ & $-.300 * *$ & $-.278 * *$ & $-.341 * *$ \\
\hline
\end{tabular}

$* * p<0.01 ; * p<0.05$ 
Referring to the dimensions of the self-blame, it can be noted that there is a weak and significant negative relationship with seven dimensions of students' resilience which the self-assurance dimension $(r=-288, p<.01)$, personal vision $(r=-276, p<. .01)$, flexible $(r=.232, p<.01)$, organized $(r=-226, p<.01)$, problem solver $(r=-.270, p<.01)$, interpersonal efficiency $(r=-.147, p<.01)$, and proactive $(r=-17, p<.01)$. Whereas, the results of the analysis showed that there was no significant relationship between self-blame dimension with the dimension of socially connected $(r=-059, p>.05)$. However, the findings show that there is a weak and significant negative relationship between the self-blame dimension and the overall resilience variable $(r=-.256, p$ $<.01)$, as well as explaining that the higher level of resilience of respondents, the lower level of self-blame for the cognitive distortion experienced by respondents.

Furthermore, the helplessness dimensions also show a weak and significant negative relationship with all dimensions of resilience which the self-assurance dimension $(r=-.369, p<.01)$, personal vision $(r=-37, p<.01)$ flexible $(r=-340, p<.01)$, organized $(r=-.239, p<.01)$, problem solver $(r=$ $-368, p<.01)$, interpersonal competence $(r=-.208, p<.01)$, socially connected $(r=-126, p<.05)$, proactive $(r=.239, p<.01)$, and overall resilience variables $(r=-.341, p<.01)$. These findings explain that the higher level of students' resilience, the lower helplessness level of cognitive distortion experienced by students.

Besides, hopelessness dimension also has a weak and significant negative relationship with all dimensions of self-resilience which are the self-assurance dimension $(r=.354, p<.01)$, personal vision $(r=-.304, p<.01)$ flexible $(r=-.302, p<.01)$, organized $(r=-.152, p<.01)$, problem solver $(r$ $=-341, p<.01)$, interpersonal competence $(r=-.158, p<.01)$, socially connected $(r=-132, p<.05)$, proactive $(r=-.215, p<.01)$, and overall resilience variables $(r=-.300, p<.01)$. These results explain that the higher level of student's self-resilience, the lower level of cognitive distortion in terms of hopelessness.

Referring to the preoccupation with danger dimension, the findings in Table 5 show a weak and significant negative relationship with all dimensions of resilience which are the self-assurance dimension $(r=-327, p<.01)$, personal vision $(r=-.214, p<.01)$, flexible $(r=-.257, p<.01)$, organized $(r=-.254, p<.01)$, problem solver $(r=-226, p<.01)$ interpersonal competence $(r=-$ $.150, p<.01)$, socially connected $(r=-.233, p<.01)$, proactive $(r=-129, p<.05)$, and overall resilience variables $(r=.-.278, p<.01)$. These findings explain that the higher students' resilience, the lower level of preoccupation with danger for cognitive distortion experienced by them.

Overall, the correlation analysis shows that there is a weak and significant negative relationship between cognitive distortion variable and all dimensions of resilience which are the selfassurance dimension $(r=-384, p<.01)$, personal vision $(r=-326, p<.01)$, flexible $(r=-325, p<.01)$, organized $(r=-2667, p<.01)$, problem solver $(r=-341, p<.01)$ interpersonal competence $(r=-$ $194, p<.01)$, socially connected $(r=-.157, p<.01)$, as well as proactive $(r=-.225, p<.01)$, and also 
resilience variable as a whole $(r=-341, p<.01)$. These findings show that the higher level of resilience, the lower level of cognitive distortion experienced by students.

\section{Conclusion}

The findings show that generally, Daily National Secondary School's students have a moderate level of family functioning (Pallant, 2014) which according to Olson et al. (1984) it refers to the form of a satisfactory and good family functioning. Based on the explanation by Olson and Tiesel (1991), the results show that the respondents' family functioning is generally connected and flexible. Students are also seen to have a moderate level of resilience and a low level of cognitive distortion. Besides that, the findings also show that there is a significant relationship between the three variables studied.

Overall, the study's findings show that there was a weak and significant positive relationship between family functioning, all dimensions of resilience and overall resilience variables. In addition, the correlation analysis also demonstrates a weak and significant negative relationship between family functioning and cognitive distortion experienced by respondents, especially for dimensions of self-criticism and self-blame. Furthermore, resilience is also generally found to have a weak and significant negative relationship with cognitive distortion experienced by respondents, as well as all dimensions involved. These findings indirectly illustrate that the excellent generation of students and leadership can be developed through efforts by building balanced family functioning as well as high resilience to prevent cognitive distortion problems among students who are the future leader of the nation.

Therefore, based on the results of this study, hopefully that the stakeholders and the parties involved in developing brilliant student generation, will be able to understand, practice, and pay attention to strengthen the discussed dimensions in the effort to nurture the family's functioning, resilience, and healthy cognitive. From the perspective of the knowledge treasure, it is hoped that the results of this study can be used as a reference and a source of useful information by other researchers especially in psychology and education fields.

\section{Acknowledgments}

We express our deepest gratitude to Malaysian Ministry of Education, Centre for Research Excellence \& Incubation Management (CREIM), UniSZA, Malaysia for supporting this publication.

\section{Corresponding Author}

Siti Hajar Mohamad Yusoff, Ph. D, Department of Usuluddin, Faculty of Islamic Contemporary Studies, Universiti Sultan Zainal Abidin (UniSZA), Kampus Gong Badak, 21300 Kuala Nerus. Terengganu, Malaysia.

Email: shajarmy@unisza.edu.my 
INTERNATIONAL JOURNAL OF ACADEMIC RESEARCH IN BUSINESS AND SOCIAL SCIENCES

Vol. 9, No. 11, November, 2019, E-ISSN: 2222-6990 @ 2019 HRMARS

\section{References}

Amoateng, A. Y., \& Richter, L. M. (2007). Chapter 1: Social and economic of families and households in South Afric. In A. Y. Amoateng \& T. B. Heaton (Eds.), Families and households in post-apartheid South Africa: sociodemographic perspectives (pp. 1-25). Cape Town: HSRC Press.

Azizi, Y., Yusof, B., Shahrin, H., Sharif, M., \& Zurhana, M. (2008). Indeks perlakuan buli di kalangan pelajar-pelajar di sekolah menengah dan rendah di Malaysia. Skudai: UTM. Dimuat turun daripada eprints.utm.my/5853/1/78069.pdf

Bahremand, M., Rai, A., Alikhani, M., Mohammadi, S., Shahebrahimi, K., \& Janjani, P. (2015). Relationship between family functioning and mental health considering the mediating role of resiliency in type 2 diabetes mellitus patients. Global Journal of Health Science, 7(3), 254-259. doi: 10.5539/gjhs.v7n3p254

Besharat, M. (2007). Resiliency, vulnerable and mental health. Journal of Psychological Science, 6(24), 373-383.

Brian, A. R. (2015). Peranan komunikasi keluarga dalam menanggulangi kenakalan remaja di Kelurahan Tataaran 1 Kecamatan Tondano Selatan. EJournal Acta Diuma, 4(4): 1-8.

Briere, J. (1996). A self-trauma model for treating adult survivors of severe child abuse. In J. Briere, L. Berliner, J. A. Bulkley, C. Jenny, \& T. Reid (Eds.), The APSAC handbook on child maltreatment (pp. 140-157). Thousand Oaks, CA: Sage.

Briere, J. (2000). The Cognitive Distortions Scales professional manual. Odessa, FL: Psychological Assessment Resources.

Farhana, F. K. (2010, Disember 24). Remaja cenderung bunuh diri. Utusan Online. Dimuat turun daripada http://ww1.utusan.com.my/utusan/ info.asp?y=2010\&dt=1224 \&pub=Utusan_Malaysia\&sec=Keluarga.

Fauziah, I., Bahama, A. S., Mansor, A. T., \& Shatar, M. S. (2012). Drug addicts and the high risk situations of relapse. Journal of Social Sciences and Humanities, 7(1), 38-49.

Harris, E. C., \& Barraclough, B. (1997). Suicide as an outcome for mental disorders: a metaanalysis. British Journal of Psychiatry, 170, 205-228.

Jamie, M. B. (2011) Psychological factors associated with bullying typologies in a mental health population of adolescents. (Disertasi Sarjana yang tidak diterbitkan). Philadelphia College of Osteopathic Medicine, Bolton.

Jaradat, M. A., ALkhazaleh, M. H. A. (2018). The Effect of Liquidity, Administrative Efficiency and Capital Adequacy on the Profitability of Jordanian Banks listed on the Amman Stock Exchange, International Journal of Academic Research in Accounting, Finance and Management Sciences 8 (4): 183-194

Khalim, Z. (2008). Memahami tingkah laku remaja bermasalah dari perspektif teori tingkah laku, humanistik, psikoanalitik dan tret personaliti. Jurnal Pengajian Umum, 9(4): 43-56.

Krejcie, R. V., \& Morgan, D. W. (1970). Determining sample size for research. Educational and Psychological Measurements, 30, 607-610.

Leahy, R. L. (1996). From practicing cognitive therapy: a guide to interventions. NYC: Cornell University Medical College and the American Institute for Cognitive Therapy. 
INTERNATIONAL JOURNAL OF ACADEMIC RESEARCH IN BUSINESS AND SOCIAL SCIENCES

Vol. 9, No. 11, November, 2019, E-ISSN: 2222-6990 @ 2019 HRMARS

Maniam, T. (2010). Hidup atau mati: masalah bunuh diri di Malaysia dari perspektif psikiatri. Bangi: UKM.

Manoli, P. (2019). Promoting students' critical literacy through the use of popular culture texts in the formal language classroom. Multilingual Academic Journal of Education and Social Sciences, 7(1), 52-61

Nasrudin, S., Suhaimi, M., \& Lokman H. (2013). Potensi konflik di antara pegangan Islam dan identiti seksual: simptom psikologikal dalam kalangan mak nyah. Journal of Psychology and Human Development, 1, 44-48.

Nyarko, K., \& Amissah, C. M. (2014). Cognitive distortion and depression among undergraduate students. Research of Humanities and Social Sciences, 4(4), 69-75.

Olson, D. H., Russell, C. S., \& Sprenkle, D. H. (1979). Cicumplex Model of marital and family systems: cohesion and adaptability dimensions, family types, and clinical applications. Family Process, 18(1), 3-28. doi:10.1111/j.15455300.1979.00003.x

Olson, D. H., Russell, C. S., \& Sprenkle, D. H. (1984). Circumplex Model of Marital and Family Systems VI: theoretical Update. In: D. H. Olson \& P. M. Miller (Eds.), Family studies review yearbook (pp. 122-134). New Delhi: Sage Publications.

Olson, D. H. (1991). Three dimensional (3-D) Circumplex Model and revised scoring of FACES. Family Process, 30, 74-79.

Olson, D. H., \& Tiesel, J. W. (1991). FACES III update: linear scoring and interpretation. Minneapolis, MN: Life Innovations, Inc.

Olson, D. H., Portner, J., \& Lavee, Y. (2003). FACES III: family version. Minneapolis, MN: Life Innovations, Inc.PPPM, 2013-2025.

Pallant, J. (2014). SPSS survival manual: a step by step guide to data analysis using SPSS. Maidenhead: Open University Press/McGraw-Hill.

Poletti, S., Colombo, C., \& Benedetti, F. (2014). Adverse childhood experiences worsen cognitive distortion during adult bipolar depression. Comprehensive Psychiatry, 55, 1803-1808. doi:10.1016/j.comppsych.2014.07.0130010-440X

Russell, J., \& Russell, L. (2003). Leading change training. Alexandria, VA: ASTD Press.

Russell, J., \& Russell, L. (2006). The 2006 Pfeiffer Annual Training: measuring employee resilience. USA: Russell Consulting, Inc.

Romli, T. R. M., Othman, M. Z., Abdullah, M. H., \& Hamat, M. Z. A. (2018). Word Classification in the Online Database of Malay-Arabic Comparable Phrases. International Journal of Academic Research in Progressive Education and Development, 7(4), 255-266

Samsiah, M. J., Aziz, M. S. M. A., \& Noraini, I. (2015). Kesan modul latihan kaunseling kesihatan mental dan trauma terhadap kecekapan amalan kaunseling dalam kalangan kaunselor di Malaysia. (Tesis Kedoktoran yang tidak diterbitkan). Universiti Pendidikan Sultan Idris, Perak.

Schafer, G. (2011). Family functioning in families with alcohol and other drug addiction. Social Policy Journal of New Zealand, 37, 135-151.

Simon, R. I. (1992). Concise guide to psychiatry and the law for clinicians. Washington, DC: American Psychiatric Press. 
Hajar, S. M. Y. (2017). Pengaruh kefungsian keluarga terhadap pengherotan kognitif dan ketahanan diri sebagai perantara. (Tesis Kedoktoran yang tidak diterbitkan). UUM Sintok, Kedah.

Hajar, S. M. Y. \& Yahya, D. (2016). Kefungsian keluarga dan pengherotan kognitif dalam kalangan belia di Institut Kemahiran Belia Negara Malaysia. Jurnal Psikologi Malaysia. 30(1): 9-16.

Hajar, S. M. Y., Shakirah, N. A., \& Fatimah, S. (2018). Pendekatan isqat tadbir al-'uyub dalam memperkasakan ketahanan diri wanita. International Seminar on al-Quran in Contemporary Society 2018, 15-16 September 2018, FKI, UniSZA, Terengganu. p. 440-455.

Shafeq, S. M., \& Hairiza, O. (2009). Kategori masalah pelajar Tahun 1, Kolej Tun Razak, Universiti Teknologi Malaysia, Skudai, Johor. Journal of Educational Psychology and Counseling, 1, 44-58.

Williams, C. J., \& Garland, A. (2002). A cognitive-behavioural therapy assessment model for use in everyday clinical practice. Advances in Psychiatric Treatment, 8, 172 - 179.

Wisena, J. B. D., Maslihah, S., \& Nurendah, G. (2016). Learned Helplessness Children in Situations CSEC (Commercial Sexual Exploitation of Children). UPI, Bandung. Dimuat turun daripada seminar.uny.ac.id/...uny.../Jaka\%20 Artikel\%20llmiah.doc.

Yaakob, D., Yahya, D., Isha, M. A., Hajar, S. M. Y., Kamaruddin, K., \& Shukri, Z. (2017). Kefungsian keluarga dalam kalangan belia di Malaysia. Malaysian Journal of Youth Studies, 17(1): 117.

Zainah, A. Z., Rohany, N., Asmawati, D., Rozainee, K., Fatimah, Y., \& Hajar, S. M. Y. (2013). Kefungsian keluarga, pengherotan kognitif dan resilien dalam kalangan klien Cure and Care Rehabilitation Centre (CCRC) dan Klinik Cure and Care (C\&C). Jurnal Psikologi Malaysia, 27, 137-149.

Zauszniewski, J. A., Bekhet, A. K., \& Suresky, M. J. (2009). Relationships among stress, depressive cognitions, resourcefulness and quality of life in female relatives of seriously mentally ill adults. Mental Health Nursing, 30(3), 142-150. doi: 10.1016/j.cnur.2010.06.001

Zauszniewski, J. A., Bekhet, A. K., \& Suresky, M. J. (2010). Resilience in family members of persons with serious mental illnes. Nursing Clinics of North America, 45(4), 613-260. doi: 10.1016/j.cnur.2010.06.007

Zuria, M., Noriah, M. I., \& Amla, M. S. (2003). Strategi kaunseling dalam menangani masalah pelajar di sekolah: satu sorotan literatur. Kertas kerja. Konvensyen PERKAMA ke XI, Hotel Eden, Johor Bahru. 